\title{
Correction to: ZIKA virus elicits P53 activation and genotoxic stress in human neural progenitors similar to mutations involved in severe forms of genetic microcephaly
}

Vincent El Ghouzzi', Federico T. Bianchi², Ivan Molineris², Bryan C. Mounce', Gaia E. Berto², Malgorzata Rak', Sophie Lebon', Laetitia Aubry ${ }^{4}$, Chiara Tocco ${ }^{2}$, Marta Gai', Alessandra M. A. Chiotto², Francesco Sgrò², Gianmarco Pallavicini ${ }^{2}$, Etienne Simon-Loriere ${ }^{5,6}$, Sandrine Passemard ${ }^{1,7}$, Marco Vignuzzi ${ }^{3}$, Pierre Gressens $s^{1,8}$ and Ferdinando Di Cunto 2,9

Correction to: Cell Death and Disease 7, e2440 (2016); https://doi.org/10.1038/cddis.2016.266; published online 27Oct 2016.

The authors wish to point out that the name of the first author is appearing incorrectly on Pubmed: it should be El Ghouzzi V (and not Ghouzzi VE). In addition, the words "and p53" appear at the end of the title in the original publication (https://www.nature.com/articles/cddis2016266) and in the previous erratum version (https://www.nature. com/articles/cddis2016446). This is not correct.

Published online: 20 November 2018

\footnotetext{
Correspondence: Pierre Gressens (pierre.gressens@inserm.fr) or

Ferdinando Cunto (ferdinando.dicunto@unito.it)

'PROTECT, INSERM, Unversité Paris Diderot, Sorbonne Paris Cité, Paris, France ${ }^{2}$ Department of Molecular Biotechnology and Health Sciences, Molecular Biotechnology Centre, University of Turin, Turin, Italy

${ }^{3}$ Institut Pasteur, Centre National de la RechercheScientifique UMR 3569, Viral Populations and Pathogenesis Unit, Paris, France

${ }^{4}$ UEVE UMR 861, I-Stem, AFM, Evry, France

${ }^{5}$ Institut Pasteur, Functional Genetics of Infectious Diseases Unit, Paris 75724, France

${ }^{6}$ CNRS URA3012, Paris 75015, France

${ }^{7}$ Département de Génétique, Hôpital Robert Debré, Paris, France

${ }^{8}$ Center for Developing Brain, King's College, London, UK

${ }^{9}$ Neuroscience Institute of Turin, Turin, Italy

These authors contributed equally: Vincent El Ghouzzi, Federico T Bianchi, Ivan

Molineris
}

(c) (i) Open Access This article is licensed under a Creative Commons Attribution 4.0 International License, which permits use, sharing, adaptation, distribution and reproduction in any medium or format, as long as you give appropriate credit to the original author(s) and the source, provide a link to the Creative Commons license, and indicate if changes were made. The images or other third party material in this article are included in the article's Creative Commons license, unless indicated otherwise in a credit line to the material. If material is not included in the article's Creative Commons license and your intended use is not permitted by statutory regulation or exceeds the permitted use, you will need to obtain permission directly from the copyright holder. To view a copy of this license, visit http://creativecommons.org/licenses/by/4.0/. 